
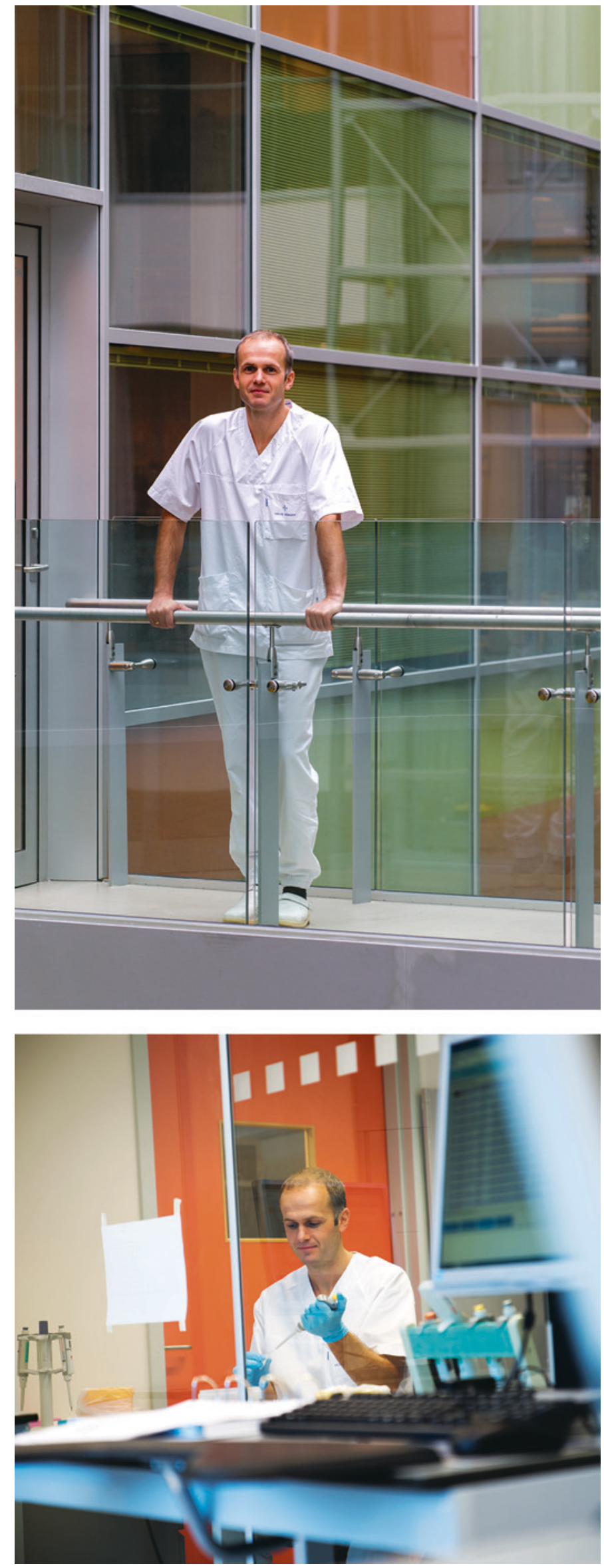

Foto: Magne Sandnes

\section{Molekylærbiologisk revolusjon}

Øyvind Kommedal er spesialist i medisinsk mikrobiologi og jobber som overlege ved Haukeland universitetssykehus. Han forteller at DNA-baserte tester vil få stadig større betydning for pasientbehandlingen.

\section{Skjer det noe interessant innen mikrobiologien for tiden?}

Medisinsk mikrobiologi står midt i en molekylærbiologisk revolusjon. Først kom DNA-sekvensering som endret måten å klassifisere mikrobene på. Siden har det kommet andre arvestoffbaserte tester som PCR, og alt er hurtig blitt lettere å utføre slik at vi også har kunnet ta dem i bruk i klinisk mikrobiologi. Disse nye metodene har hevet kvaliteten på de mikrobiologiske analysene og gitt en betydelig kortere svartid. Prøvesvarene kan i større grad enn tidligere få direkte konsekvenser for den enkelte pasient og har ført til debatter om utvidet åpningstid for laboratoriene. Ved Haukeland universitetssykehus har vi derfor utvidet driften til kl. 22 alle hverdager. Jeg tror at etterspørselen etter raske svar vil tilta, særlig når vi begynner med genetisk resistenstesting av enkelte bakterier.

\section{Vil du anbefale en ny og spennende artikkel?}

Såkalt neste generasjons sekvensering er det alle snakker om for tiden. Denne metoden gir enorme muligheter innenfor alt fra studier av normalflora til utbruddskartlegging. Actionable diagnosis of neuroleptospirosis by next-generation sequencing er en artikkel i New England Journal of Medicine (NEJM) hvor man beskriver en meget konkret og nyttig klinisk anvendelse, nemlig muligheten til å påvise ethvert agens - virus, bakterie, sopp eller parasitt - i en hvilken som helst prøve uten på forhånd å måtte definere hva man ønsker å se etter (1). En universell mikrobiologisk screeningtest! Det er noen år frem til dette er tilgjengelig i vanlig rutinediagnostikk, men i løpet av fem år tror jeg vi vil kunne tilby dette ved alvorlige infeksjoner.

\section{Hva er ditt favoritthjelpemiddel på jobb?}

Det må være GenBank (2). Dette er en database som inneholder alle kjente gensekvenser fra enhver organisme. Alle som skal publisere en artikkel der gensekvenser utgjør en sentral del, er nødt til å legge gensekvensene med tilhørende beskrivelse inn i denne databasen. En av de mest sentrale funksjonene i databasen er muligheten for å sammenlikne DNA-sekvenser. Hvis du har sekvensert et gen, for eksempel for å typebestemme et enterovirus, sammenlikner du ganske enkelt din sekvens med tilsvarende sekvenser i databasen via en søkefunksjon. Slik kan du se hvilket enterovirus ditt virus er nærmest beslektet med.

\section{Anbefalt litteratur}

1. Wilson MR, Naccache SN, Samayoa E et al. Actionable diagnosis of neuroleptospirosis by next-generation sequencing. N Engl J Med 2014; 370: 2408-17.

2. Databasen GenBank. www.ncbi.nlm.nih.gov/genbank/ (13.10. 2015).

Har du tips til personer vi kan intervjue? Ta kontakt med elena.aandstad@legeforeningen.no 